\section{Paper Sludge Amendments for Turfgrass}

\author{
J. Norrie ${ }^{1}$ and A. Gosselin \\ Department of Plant Science, Horticultural Research Center, Laval University, \\ Ste-Foy, Quebec G1K 7P4, Canada
}

Additional index words. deinked and primary paper sludge, ground cover, Kentucky bluegrass, Poa pratensis, perennial ryegrass, Lolium perenne, turf quality

\begin{abstract}
The behavior of turfgrass grown on paper-sludge-amended soils was evaluated over 2 years. Two experiments were performed, one with deinked sludge and another with primary sludge. Four paper sludge, sand, and organic soil substrate mixtures with proportions ranging from $0 \%$ to $50 \%$ paper sludge were incorporated into existing soils. Two fertilization levels were applied in strip plots across sludge treatments and three turfgrasses of seeded Kentucky bluegrass (Poa pratensis L. 'Georgetown'), Kentucky bluegrass sod, and an 80 Kentucky bluegrass : 20 perennial ryegrass (Lolium perenne $\mathrm{L}$. 'Prelude') seed mix were arranged within split plots. Effects of deinked and primary sludge experiments were similar. Supplemental $\mathbf{N}$ and, to a lesser degree, $\mathbf{P}$ and $\mathbf{K}$ fertilization with $\mathrm{N}$ at $\approx 4.5$ to $5.5 \mathrm{t} \cdot \mathrm{ha}^{-1}, \mathrm{P}$ at 1.18 to $1.26 \mathrm{t} \cdot \mathrm{ha} \mathrm{a}^{-1}$, and $\mathrm{K}$ at 1.34 to $1.46 \mathrm{t} \cdot \mathrm{ha}^{-1}$ improved ground cover, turf color, and stand quality. Despite differences in visual evaluations, leaf mineral nutrition was only slightly affected by fertilization treatments. Soil in nonfertilized plots was several times lower in $\mathrm{N}-\mathrm{NO}_{3}$ when compared to fertilized plots, regardless of sludge rate. Soil in fertilized plots had higher concentrations of inorganic $N$ regardless of sludge amendment. The soil $C: N$ ratio was $\approx 13: 1$ in nonamended plots and more than 15:1 under the highest sludge rate. Deinked and primary paper sludges can be used effectively as soil amendments if turfgrass receives adequate supplemental $\mathbf{N}, \mathbf{P}$, and $\mathrm{K}$.
\end{abstract}

Paper sludges are receiving increasing attention as potential organic soil amendments and conditioners [Barclay, 1991; National Council for Air and Stream Improvement (NCASI), 1984, 1991; Quebec Ministry of the Environment, 1984]. Increased landfill costs and mounting pressure to reduce incineration of organic residuals support call for the evaluation of fresh and composted sludges. Paper manufacturers are examining benefits from primary (residual virgin wood fibers), secondary (biological waste-water treatment), and deinked (recycled) sludge applications to recondition agricultural and urban soils (Enzor, 1988; Seckins, 1986). However, sludge composition varies considerably due to the papermaking process and, for deinked sludges, depends on recycled paper sources and the deinking process used. In general, deinked sludges are composed of lignin and cellulose fibers, clay fillers, and coating agents used in the papermaking process (Dyer et al., 1984; Seckins, 1986). A survey of several paper mills found that the macronutrient content of nonamended deinked sludges was low, varying from $0.14 \%$ to $4.1 \% \mathrm{~N}, 0.001 \%$ to $2.54 \%$ $\mathrm{P}$, and $0.012 \%$ to $1.0 \% \mathrm{~K}$, on a dry-mass basis (NCASI, 1984).

Received for publication 16 Nov. 1995. Accepted for publication 2 Apr. 1996. This project was supported by Les Composts du Quebec. The cost of publishing this paper was defrayed in part by the payment of page charges. Under postal regulations, this paper therefore must be hereby marked advertisement solely to indicate this fact.

${ }^{1}$ Research Scientist. Current address: Acadian Seaplants, 30 Brown Ave., Dartmouth, Nova Scotia B3B 1 X8.

HortScience, Vol. 31(6), October 1996
The objective of our study was to evaluate ground cover and stand quality of two turfgrasses grown on soils amended with deinked and primary paper sludges. Supplemental $\mathrm{N}, \mathrm{P}$, and $\mathrm{K}$ fertilization effects on sludge soil and leaf nutrition were also examined.

\section{Materials and Methods}

Project site and experimental design. The experiment was conducted on the campus of Laval Univ., Ste-Foy, Quebec. Raw deinked and primary sludge treatments were evaluated in separate experiments. Paper sludges from the Daishowa papermill (Quebec, Canada) were used as constituents in substrate mixtures incorporated into indigenous soils (Table 1). A strip split-plot design with four replications was used to evaluate four paper sludge mixtures, two fertilization levels, and three turfgrass treatments.

Substrate mixtures. Four substrate mixtures characterized by increasing rates of paper sludge and decreasing rates of organic soil were randomized in $4 \times 6-\mathrm{m}$ main plots. Paper sludge : organic soil ratios were 0:50, 10:40, 30:20, and 50:0 by volume. The organic soil (terre noire) originated from lots 490 and 491 of the Canton Bellaire deposit, located southeast of St-Jean-Chrysostome, Quebec. Compared to peat, the organic soil is more decomposed, highly mineralized, less acidic, and does not possess the same fibrous texture. The organic soil has $\mathrm{pH} 6$ to 6.5 and is composed of $40 \%$ to $50 \%$ organic matter and has been given a decomposition rating of between 5 and 7 according to the Von Post scale (Buteau, 1986; Commission Canadienne de Pédologie, 1978). A $50 \%$ sand fraction (medium horticultural grade, particle size: 0.25 to $0.5 \mathrm{~mm}$ ) having a $\mathrm{pH}$ of 8 , electrical conductivity of 0.15 $\mathrm{dS} \cdot \mathrm{m}^{-1}, 0.5 \%$ total $\mathrm{C}$, and $0.02 \%$ total $\mathrm{N}$ also was maintained in each mixture. The sand was analyzed (Mehlich III) as having (in $\mathrm{mg} \cdot \mathrm{kg}^{-1}$ ) $10 \mathrm{P}, 25 \mathrm{~K}, 80 \mathrm{Mg}$, and $4030 \mathrm{Ca}$. A 15 -cm layer of each of the four substrate mixtures was spread over experimental main plots and incorporated to a depth of $30 \mathrm{~cm}$. These represented dry sludge application rates of $\approx 0,23$, 68 , and 113 toha ${ }^{-1}$.

provements in soil physical and chemical properties may be realized by mixing sludges with sand, soil, or both composed of a high organic matter content (unpublished data).

Market testing has shown that fresh (Enzor, 1988) and composted sludges are popular with landscape contractors, nurseries, greenhouses, and municipal agencies (Smyser, 1982). Applications to agricultural fields are common in several states, with up to $100 \%$ of available sludges being applied during months of high demand. Field application rates usually range between 9 and 224 dry thha ${ }^{-1}$ (dry mass), depending on agricultural or silvicultural uses (Bockheim et al., 1988; Thacker, 1985; Watson and Hoitink, 1985). Although several studies have examined sludge mixtures in container crop production (Chong, 1993; Chong and Cline, 1993; Chong et al., 1987), the current literature lacks information on the use of fresh sludge amendments for turfgrass culture.
Table 1. Analysis of indigenous schist-loam soil before application and incorporation of papersludge mixtures.

\begin{tabular}{|c|c|}
\hline Variable & Value \\
\hline $\mathrm{pH}-\mathrm{H}_{2} \mathrm{O}$ & 6.1 \\
\hline $\mathrm{pH}$ buffer & 6.48 \\
\hline Organic matter $(\%)$ & 2.18 \\
\hline Total N (\%) & 0.18 \\
\hline Available P $\left(\mathrm{kg} \cdot \mathrm{ha}^{-1}\right)$ & 420 \\
\hline Exchangeable K $\left(\mathrm{kg} \cdot \mathrm{ha}^{-1}\right)^{\mathrm{z}}$ & 558 \\
\hline Exchangeable $\mathrm{Mg}\left(\mathrm{kg} \cdot \mathrm{ha}^{-1}\right)^{\mathrm{z}}$ & 164 \\
\hline Exchangeable $\mathrm{Ca}\left(\mathrm{kg} \cdot \mathrm{ha}^{-1}\right)^{\mathrm{z}}$ & 4162 \\
\hline $\begin{array}{l}\text { Cation exchange capacity } \\
\text { (meq/100 g soil) }\end{array}$ & 13.5 \\
\hline Sand $(\%)$ & 34.7 \\
\hline Loam $(\%)$ & 36.7 \\
\hline Clay $(\%)$ & 28.6 \\
\hline
\end{tabular}

${ }^{\mathrm{z}}$ Exchangeable $\mathrm{K}, \mathrm{Mg}$, and $\mathrm{Ca}$ determined by soil Mehlich III extraction/analysis. 
Fertilization treatments. Two 2-m-wide fertilization treatments were stripped horizontally across main plots. One of the two strip plots was given supplemental $\mathrm{N}, \mathrm{P}$, and $\mathrm{K}$ in sludge-amended soils and the other was not fertilized. Supplemental fertilizer levels were determined after substrate mixture analysis, before sludge/soil incorporation, with fertilizer rates increasing with increasing sludge content. Fertilizer application resulted in $\left(\mathrm{t} \cdot \mathrm{ha}^{-1}\right) \approx 4.5$ to $5.5 \mathrm{~N}, 1.18$ to $1.26 \mathrm{P}$, and 1.34 to $1.46 \mathrm{~K}$. Fertilizers were distributed evenly by hand and incorporated with a rototiller to a depth of $30 \mathrm{~cm}$. A general fertilization of $21 \mathrm{~N}-$ $3 \mathrm{P}-7 \mathrm{~K}$ at $200 \mathrm{~kg} \cdot \mathrm{ha}^{-1}$ was applied to both strip plots after emergence in late July to parallel regular turf fertilization patterns.

Evaluation of grass types. Three turfgrass treatments were placed vertically across main plots in mid-July 1993 into $2 \times 2$-m split plots, consisting of $100 \%$ Kentucky bluegrass sod (KB sod, unknown blend), seeded Kentucky bluegrass (KB seed, 'Georgetown'), and a seeded mixture of $80 \%$ Kentucky bluegrass and $20 \%$ perennial ryegrass (KB/PR; $P R$, 'Prelude') in mid-July 1993. Plots were mowed twice weekly to $\approx 4 \mathrm{~cm}$ and clippings were removed. Sprinkler irrigation was used during the first 4 weeks of the experiment to encourage plot establishment by maintaining a moist soil surface.

Visual evaluations, soil and leaf analysis. Four independent judges each visually evaluated ground coverage (percent) and turfgrass stand quality (based on general appearance, color, and presence of weeds) in Fall 1993 and in Spring and Fall 1994. In Fall 1994, the quality rating was subdivided to include separate evaluations for stand color. Besides ground cover (percent), all evaluations were based on a 1 (poor) to 10 (excellent) scale.

Soil fertility (P, $\mathrm{Mg}, \mathrm{Ca}, \mathrm{K}, \mathrm{Na}, \mathrm{Cu})$ for the sodded turf treatments was analyzed at the end of each season using the Mehlich III extraction technique. Electrical conductivity (EC) and $\mathrm{pH}$ were measured from the soil solution $1 \mathrm{~h}$ after preparation of a 2 soil : 1 water mixture. To measure bulk density, soil cores samples $(\approx 5 \mathrm{~cm}$ in diameter) were carefully removed from experimental plots to minimize disturbance of the soil core structure. Cores were dried at $105{ }^{\circ} \mathrm{C}$, and, knowing core volume, bulk density was calculated as the dry mass divided by the volume. Inorganic $\mathrm{N}\left(\mathrm{N}-\mathrm{NO}_{3}\right.$ and $\mathrm{N}-\mathrm{NH}_{4}$ ) was analyzed by distillation after extraction with $\mathrm{KCl}(2 \mathrm{M})$. Total $\mathrm{C}, \mathrm{S}$, and $\mathrm{N}$ percentages and the $\mathrm{C}: \mathrm{N}$ ratio were measured or calculated with the LECO CNS-1000 analyzer (LECO Corp., St. Joseph, Mich.).

Leaf nutrient composition was determined following the 1994 growing season. Foliar tissues were analyzed for total $\mathrm{N}, \mathrm{P}, \mathrm{K}, \mathrm{Ca}$, $\mathrm{Mg}, \mathrm{Mn}, \mathrm{B}, \mathrm{Cu}, \mathrm{Fe}$, and $\mathrm{Zn}$. Samples were taken in Sept. 1994 from KB sod subplots and dried at $70^{\circ} \mathrm{C}$ for $48 \mathrm{~h}$ before analysis.

Statistical analysis. Data were compiled at the end of each season. An analysis of variance was carried out on all data using the SAS statistical package (SAS, 1988) and significant differences $(P \leq 0.05$ and 0.01$)$ between treatment means were identified. Specific hy-
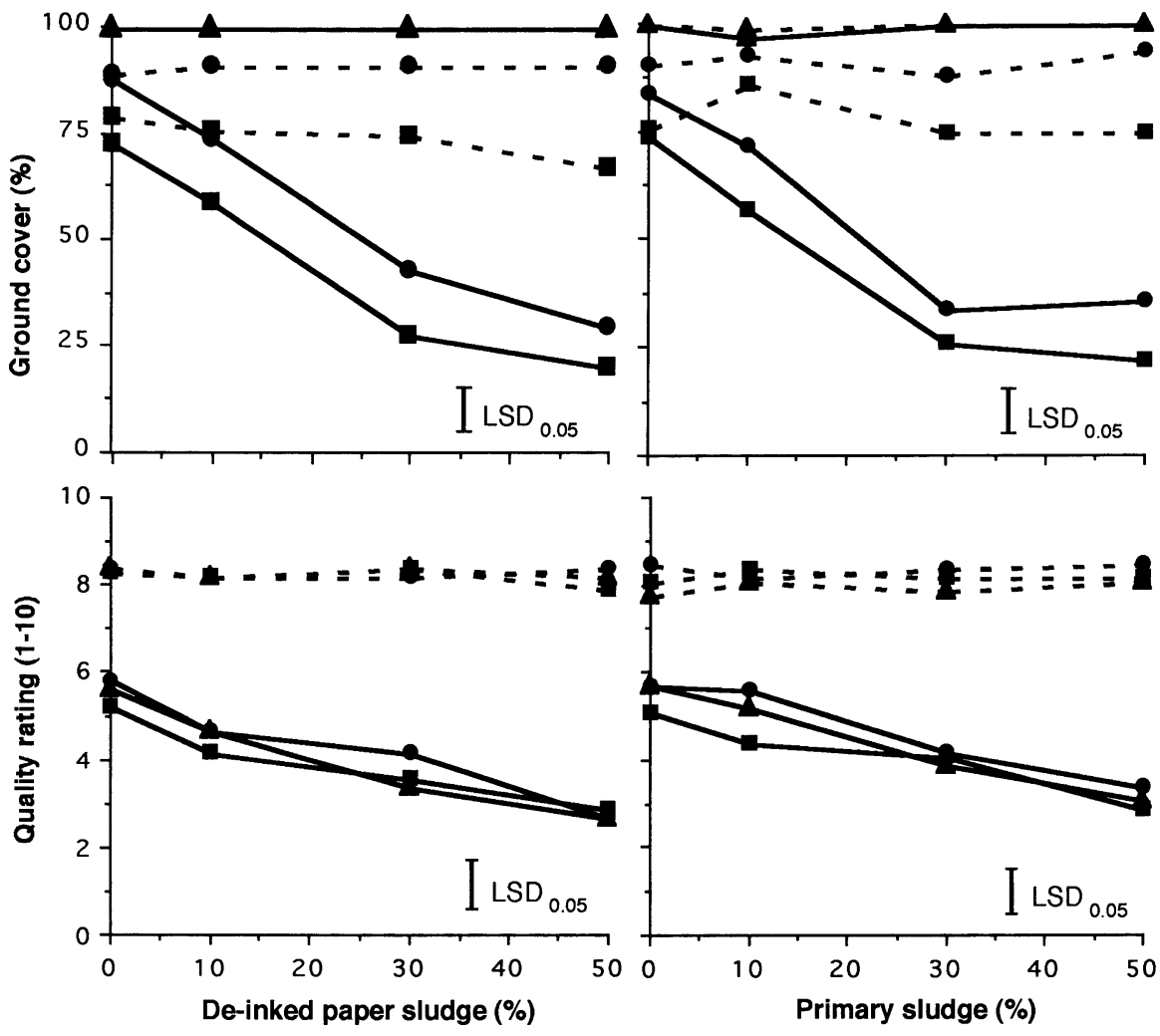

Fig. 1. Evaluation of the percent ground cover and stand quality of grasses cultivated on sludge-amended

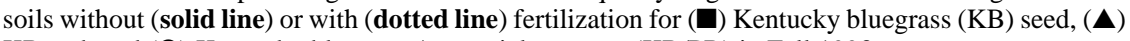
KB sod, and (-) Kentucky bluegrass/perennial ryegrass (KB/PR) in Fall 1993.
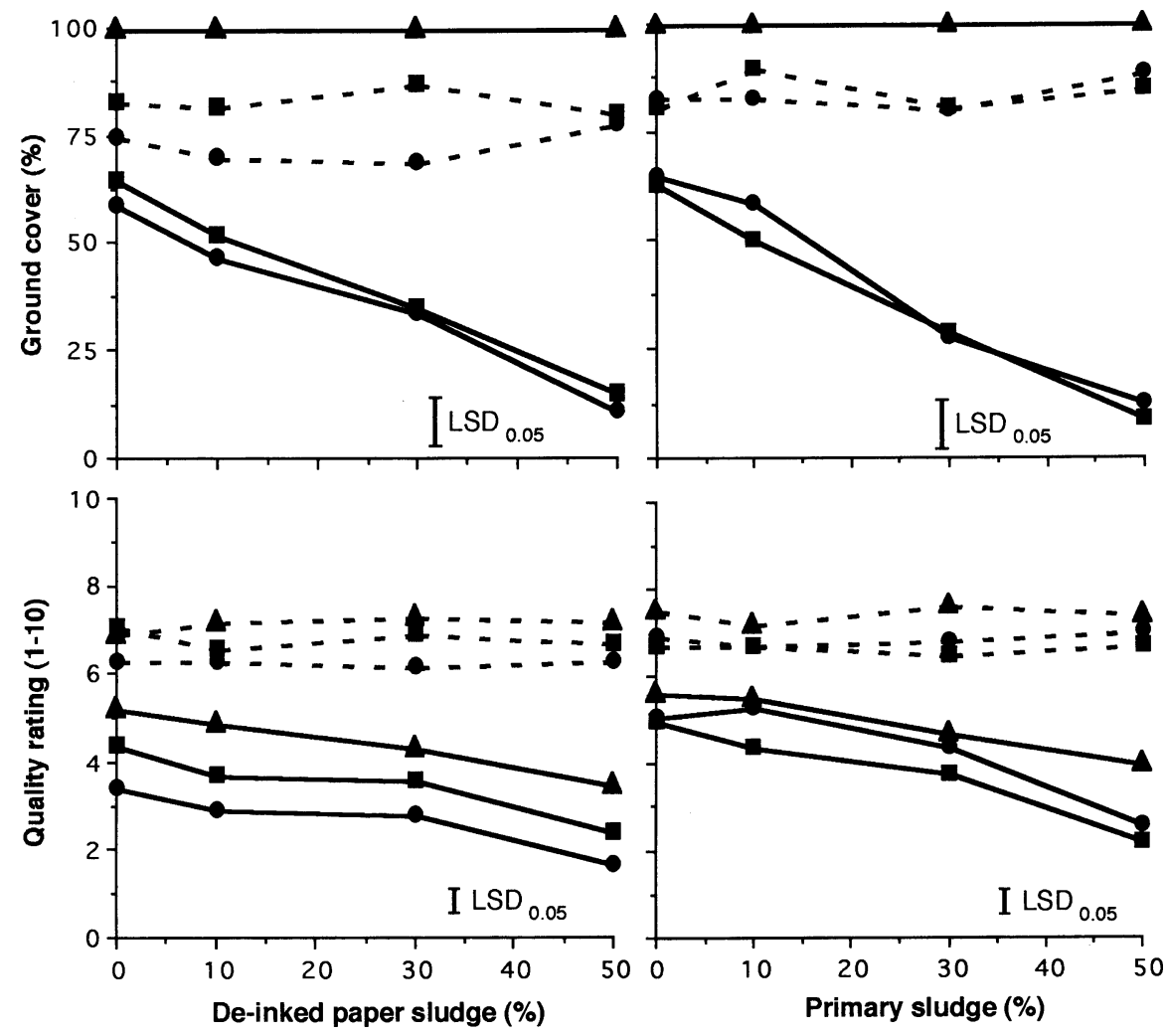

Fig. 2. Evaluation of the percent ground cover and stand quality of grasses cultivated on sludge-amended soils without (solid line) or with (dotted line) fertilization for (ם) Kentucky bluegrass (KB) seed, (A) KB sod, and (O) Kentucky bluegrass/perennial ryegrass (KB/PR) in Spring 1994. 
pothesis testing using designated error terms also was performed according to the strip split-plot design analysis (Gomez and Gomez, 1985; Steel and Torrie, 1988). Due to the presence of several three-way interactions, results are presented to illustrate effects of fertilizer treatments within each main plot substrate mixture, for each turfgrass type. In cases of a significant $F$, means were separated by the Fisher Protected least significant difference (LSD). Presentation of quantitative and discrete variables within the same experimental design is made according to Gomez and Gomez (1985).

\section{Results and Discussion}

Ground cover and stand quality. For $\mathrm{KB}$ sod, ground cover remained at or near $100 \%$ regardless of fertilizer treatments in Fall 1993 (Fig. 1). However, ground cover was reduced $53 \%$ in KB seed plots and $58 \%$ in KB/PR plots as deinked sludge content was increased from $0 \%$ to $50 \%$ in nonfertilized plots. Grass seeded in nonfertilized primary sludge-amended plots exhibited a similar reduction in coverage with increasing sludge content. However, with fertilization, ground cover improved to between $67 \%$ and $79 \%$ for KB seed and to more than $89 \%$ for the KB/PR mixture. In general, an increase in sludge amendment resulted in a decrease in stand quality in nonfertilized plots (Fig. 1). However, ratings were consistently higher (near or above 8 ) for all plots receiving additional fertilization.

Ground cover data taken in Spring 1994 also served as an indication of overwinter survival (Fig. 2). Increasing sludge amendments without additional fertilization resulted in a sharp decrease in ground cover for both sludge types. However, in fertilized plots, only minor differences were observed between sludge amendment treatments. Increasing content of both sludges resulted in poor stand quality in early spring evaluations in nonfertilized plots, but had no effect on stand quality in fertilized strips.

Significant growth and plot reestablishment occurred over the summer of both seasons, regardless of fertility level. As a result, many low ground cover and stand quality ratings were substantially higher in the fall than they had been in spring (Fig. 3). KB sod plots had consistently higher ground cover scores (at or near 100\%), but also had improved color and quality ratings. This tendency was true for deinked and primary sludgeamended soils.

Soil analysis. As expected, fertilized strip plots had much higher $\mathrm{N}-\mathrm{NH}_{4}$ and $\mathrm{N}-\mathrm{NO}_{3}$ concentrations than nonfertilized plots (data not shown). Regardless of sludge source, $\mathrm{N}$ $\mathrm{NH}_{4}$ concentrations ranged from 200 to 400 $\mathrm{mg} \cdot \mathrm{kg}^{-1}$ in fertilized plots and remained below $3 \mathrm{mg} \cdot \mathrm{kg}^{-1}$ in nonfertilized plots. Differences due to sludge rate were absent. $\mathrm{N}_{-} \mathrm{NO}_{3}$ levels ranged from 150 to $215 \mathrm{mg} \cdot \mathrm{kg}^{-1}$ in fertilized plots. Although levels for $\mathrm{N}-\mathrm{NO}_{3}$ were much lower in nonfertilized plots, levels were progressively reduced from $\approx 15$ to $1 \mathrm{mg} \cdot \mathrm{kg}^{-1}$ with increasing sludge, regardless of the paper

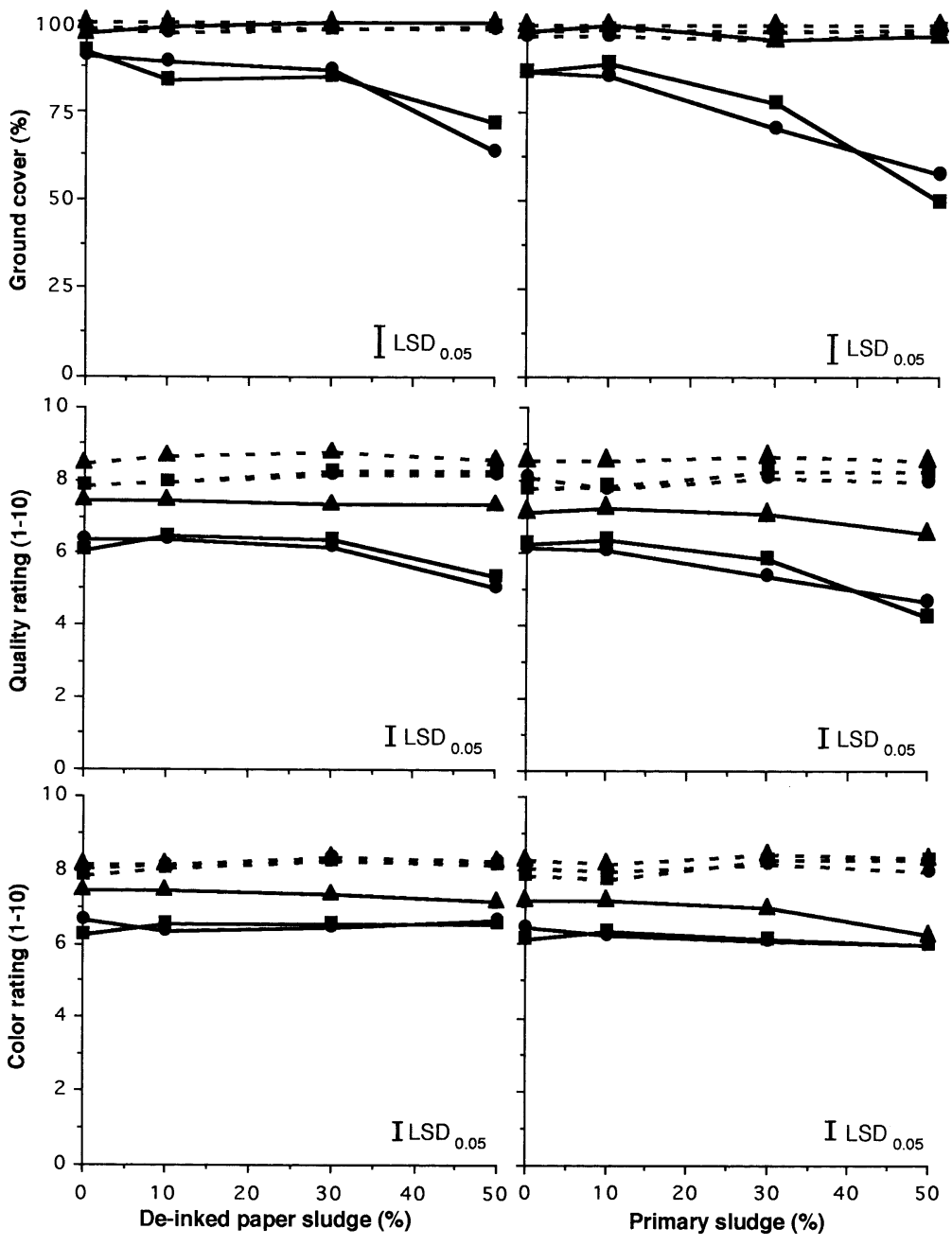

Fig. 3. Evaluation of ground cover, stand quality, and color in turf cultivated on sludge-amended soils without (solid line) or with (dotted line) fertilization for ( $\square)$ Kentucky bluegrass (KB) seed, (A) KB sod, and (-) Kentucky bluegrass/perennial ryegrass (KB/PR) in Fall 1994.

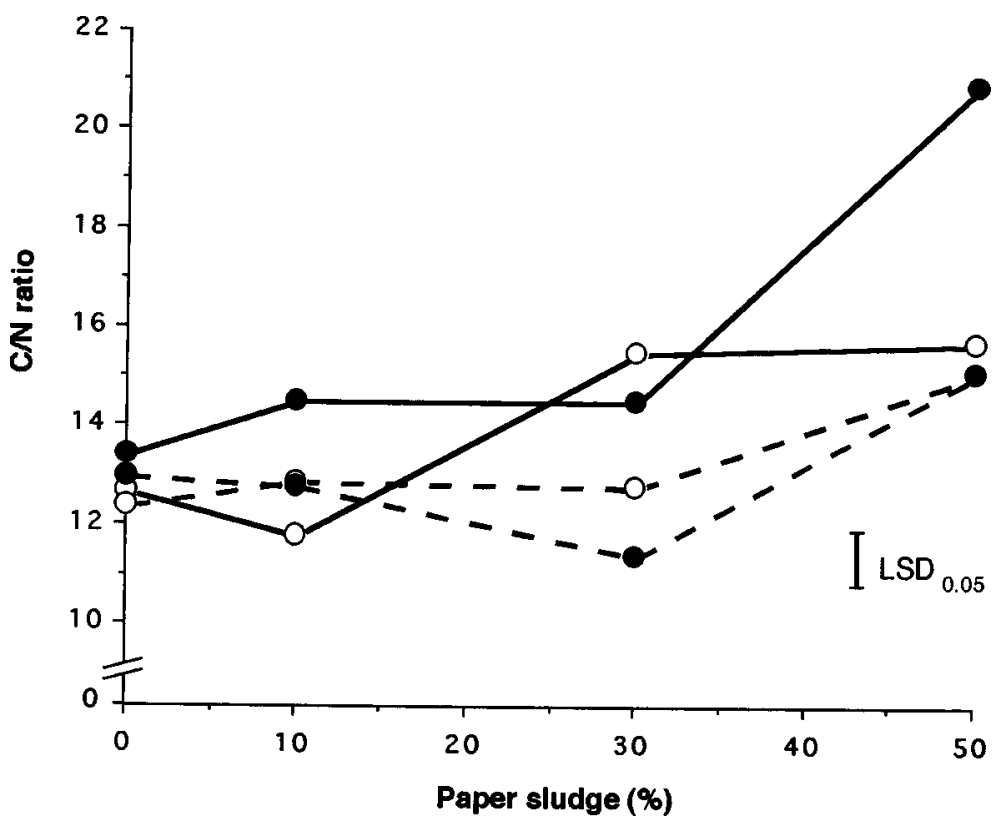

Fig. 4. Carbon : nitrogen ratio determined from $(\bigcirc)$ deinked and $(\bullet)$ primary sludge-amended soils without (solid line) or with (dotted line) fertilization for Kentucky bluegrass (KB) sod in Fall 1994. 
source. Phosphorus and K levels averaged 346 and $304 \mathrm{mg} \cdot \mathrm{kg}^{-1}$, respectively, in fertilized deinked plots and 470 and $258 \mathrm{mg} \cdot \mathrm{kg}^{-1}$, respectively, in fertilized primary sludge plots. Levels of $\mathrm{P}$ and $\mathrm{K}$ in nonfertilized deinked plots averaged 116 and $134 \mathrm{mg} \cdot \mathrm{kg}^{-1}$, respectively, and 147 and $129 \mathrm{mg} \cdot \mathrm{kg}^{-1}$, respectively, in nonfertilized primary sludge plots. Differences were not related to sludge rate. Magnesium, $\mathrm{Na}$, and $\mathrm{Cu}$ concentrations varied inconsistently between sludge treatments, while exchangeable $\mathrm{Ca}$ generally decreased with increasing sludge amendment.

The $\mathrm{C}: \mathrm{N}$ ratio was slightly higher in $50 \%$ sludge than in nonamended plots (Fig. 4), while total $\mathrm{C}$ increased only marginally (data not shown). No differences were observed between the $\mathrm{pH}$ of sludge treatments, but $\mathrm{pH}$ was generally 0.2 to 1.5 units lower in fertilized than in nonfertilized plots. The EC ranged from 0.21 to $0.12 \mathrm{dS} \cdot \mathrm{m}^{-1}$ in nonfertilized plots and, due to additional fertilizer salts, from 0.3 to $0.7 \mathrm{dS} \cdot \mathrm{m}^{-1}$ in fertilized plots for deinked and primary sludge mixtures. Bulk density ( 1.1 to $\left.1.2 \mathrm{~g} \cdot \mathrm{mL}^{-1}\right)$ and soil moisture $(0.15 \%$ to $0.2 \%$ by mass) remained relatively constant for all sludge treatments.

Plant nutrient composition. Grass leaf analysis indicated that foliar $\mathrm{B}, \mathrm{Ca}, \mathrm{Cu}, \mathrm{Mg}$, $\mathrm{Mn}$, and $\mathrm{Zn}$ levels fell within guidelines suggested by the Guelph Turfgrass Institute for optimal foliar nutrition (Ontario Ministry of Agriculture and Food, 1993). However, foliar $\mathrm{N}$ (percent) was below recommended guidelines in nonfertilized plots $(\approx 2.2 \%)$ but not in fertilized plots $(\approx 3.5 \%)$. Foliar nutrition was minimally affected by sludge rate. Higher soil $\mathrm{P}$ and $\mathrm{K}$ concentrations translated into higher foliar $\mathrm{P}$ and $\mathrm{K}$ in fertilized plots. However, $\mathrm{P}$ $(0.3 \%$ to $0.45 \%)$ and $\mathrm{K}(2.2 \%$ to $3.1 \%)$ remained within recommended guidelines for both fertilizer treatments.

\section{Conclusion}

Paper sludge mixtures generally increased soil organic matter content. However, due to low nutrient levels in sludge residues (primarily $\mathrm{N}$ ), our results indicate a need for supplemental fertilizers to correct for elevated $\mathrm{C}: \mathrm{N}$ ratios; low available $\mathrm{N}$; and sludge mixture imbalances in $\mathrm{P}, \mathrm{K}, \mathrm{S}$, and other major cations.
Dramatically improved ground cover and stand quality in fertilized plots support this conclusion. Also, sodding may be preferred to seeding, especially in areas where low fertility levels are anticipated. However, despite differences in soil fertilizer treatments and appearance, leaf nutrient levels remained adequate in fertilized and nonfertilized plots, with few exceptions. Second-year data indicate that small maintenance fertilizer applications to sludge-amended soils can contribute to the improvement of stand quality even in the absence of supplemental fertilization applications. Our results indicate that sludge application via media mixtures can improve or, at the very least, maintain soil organic matter content while not adversely affecting plant nutrition. We conclude that adequately fertilized deinked and primary paper sludges are effective soil amendments for turfgrass culture.

\section{Literature Cited}

Barclay, H.G. 1991. Heavy metal content of deinking and other mill sludges: A literature review. Pulp \& Paper Res. Inst. Canada. Misc. Rpts. MR211, Montreal.

Bockheim, J.G., T.C. Benzel, R.-L. Lu, and D.A. Theil. 1988. Groundwater and soil leachate inorganic nitrogen in a Wisconsin red pine plantation amended with paper industry sludge. J. Environ. Qual. 17(4):729-734.

Buteau, R. 1978. Propriétés physico-chimiques de la tourbe du Québec méridional en vue d'utilisations industrielles. Ministère del'Énergie et des Ressources, Québec, ET 85-09.

Chong, C. 1993. Recycling Ontario papermill sludge in nursery culture. Proc. Pulpmill Waste Utilization in the Forest. Clear Lake, Edmonton, Ont., Canada. p. 59-60.

Chong, C. and R.A. Cline. 1993. Response of four ornamental shrub shrubs to container substrate amended with two sources of raw paper-mill sludge. HortScience 28:807-809.

Chong, C., R.A. Cline, and D.L. Rinker. 1987. Spent mushroom compost and papermill sludge as soil amendments for containerized nursery crops. Proc. Intl. Plant Prop. Soc. 37:347-353.

Commission Canadienne de Pédologie. 1978. Le système canadien de classification des sols. Ministère de l'Agriculture du Canada, Direction de la Recherche, Publ. 1646, Ottawa.

Dyer, K.L., W.R. Curtis, and J.T. Crews. 1984. Response of vegetation to various mulches used in surface mine reclamation in Alabama and Kentucky: 7-year case history. Northeastern For.
Expt. Sta. General Tech. Rpt. NE-93. U.S. Dept. Agr., For. Serv.

Enzor, S.B. 1988. Virginia fibre disposes of sludge by land application. Amer. Papermaker 8:33-35.

Feagley, S., M.S. Valdez, and W. Hudnall. 1994a. Bleached, primary papermill sludge effect on bermudagrass grown on a mine soil. Soil Sci. 157:389-397.

Feagley, S., M.S. Valdez, and W. Hudnall. 1994b. Papermill sludge, phosphorus, potassium, and lime effect on clover grown on a mine soil. J. Environ. Qual. 23:759-765.

National Council for Air and Stream Improvement. 1984. The land application and related utilization of pulp and paper mill sludges. Tech. Bul. 439, New York.

National Council for Air and Stream Improvement. 1991. Characterization of wastes and emissions from mills using recycled paper. Tech. Bul. 613, New York.

Ontario Ministry of Agriculture and Food. 1993. Recommendations for turfgrass management. Publ. 384, February.

Quebec Ministry of the Environment. 1984. La réhabilitation des carrières et sablières: Un coup de main à l'environnement. Envirodoq 840091, Quebec.

SAS Institute. 1988. SAS/STAT, user's guide, release 6.03 ed. SAS Inst., Cary, N.C.

Seckins, B. 1986. Paper mill sludge. Text presented to the Forum Québecoise sur le compostage. 2:1-5. Ministère de l'Agriculture, des Pêcheries et de l'Alimentation Quebec.

Smyser, S. 1982. Compost paying its way for paper producer. Biocycle 23(3):25-26.

Steel, R.G.D. and J.H. Torrie. 1988. Principles and procedures of statistics: A biometrical approach. 2nd ed. McGraw-Hill, Toronto.

Thacker, W.E. 1986. Silvicultural land application of wastewater and sludge from the pulp and paper industry, p. 41. In: D.W. Cole, C.L. Henry, and W.L. Nutter (eds.). The forest alternative for treatment and utilization of municipal and industrial wastes. Univ. of Washington Press, Seattle.

Trépanier, L. and J. Gallichaud. 1994. Environmental impact of deinking paper mill sludge storage. Paper 946558, ASAE Intl. Winter Mtg., 13-16 Dec.

Trudelle, M. and M. Giroux. 1991. Effets de l'apport de residus de pate et papier frais et compostés sur les proprietés des sols et le rendement des cultures. Colloque sur les amendements organiques et la productivité des sols. CPVQ-AQSSS, Quebec.

Watson, M.E. and H.A.J. Hoitink. 1985. Utilizing papermill sludge: Longterm effects in stripmine reclamation. Biocycle 26(7-8):51-53. 